\title{
Effects of nitrous oxide on cardiovascular parameters in pigs \\ anesthetized with propofol and subjected to pressure-controlled ventilation
}

\author{
Efeitos do óxido nitroso sobre parâmetros cardiovasculares \\ em suínos anestesiados com propofol e mantidos em ventilação \\ controlada à pressão
}

\author{
Rodrigo Lima Carneiro ${ }^{1 *}$; Patrícia Cristina Ferro Lopes²; Ana Paula Gering 3 ; \\ Eliselle Gouveia de Faria Bitelii"; Paloma do Espírito Santo Silva ${ }^{4}$; Cléber Kazuo \\ $\mathrm{Ido}^{4}$; Helen Roberta Amaral da Silva ${ }^{4}$; Diego Iwao Yamada ${ }^{5}$ Newton Nunes ${ }^{6}$
}

\begin{abstract}
This paper evaluated the effects of the ratio of nitrous oxide to oxygen ( $50 \%$ of each) on cardiovascular parameters in pigs anesthetized with propofol and maintained in ventilation with intermittent positive pressure. Sixteen Large White pigs, weighing between 15 and $20 \mathrm{~kg}$, were divided into two groups of eight animals, and designated as follows: GPN (propofol/nitrous oxide) and GPA (propofol/compressed air). In order to allow endotracheal intubation, the animals received azaperone (2 $\mathrm{mg} \mathrm{kg}^{-1}$, IM) followed, after 20 minutes, by intravenous propofol. After successful intubation, continuous infusion of propofol was initiated at a dose of $0.4 \mathrm{mg} \mathrm{kg}^{-1}$ minute ${ }^{-1}$. From this point, the GPN group received $\mathrm{N}_{2} \mathrm{O}$ (diluted in 50\% oxygen), while the GPA group received compressed air (diluted in 50\% oxygen). Rocuronium was then administered by continuous intravenous infusion at $0.6 \mathrm{mg} \mathrm{kg}^{-1} \mathrm{~h}^{-1}$. Pressurecontrolled ventilation (PCV) was started and adjusted to $15 \mathrm{cmH}_{2} \mathrm{O}$, and the respiratory rate was set to reach capnometry readings between $35-45 \mathrm{mmHg}$. The measurement of parameters (heart rate, mean arterial pressure, cardiac index, systemic vascular resistance index, stroke index) begun 15 minutes after the administration of rocuronium, and was repeated in 15-minute intervals for 60 minutes. Data were statistically analyzed by ANOVA followed by Bonferroni test. The results showed that the 1:1 ratio combination of nitrous oxide to oxygen $(50 \%$ each) did not alter the mentioned parameters in pigs anesthetized with propofol and maintained at pressure-controlled ventilation, indicating that it is a safe protocol for the cardiovascular system.
\end{abstract}

Key words: Balanced anesthesia. Cardiac index. Hemodynamic monitoring.

\footnotetext{
${ }^{1}$ Prof., União Metropolitana para o Desenvolvimento da Educação e Cultura, UNIME, Lauro de Freitas, Brasil. E-mail: rodrigolimacarneiro27@gmail.com

2 Prof., Faculdade de Jaguariúna, FAJ, Jaguariúna, SP, Brasil. E-mail: lopesferro.patrícia@gmail.com

${ }^{3}$ Prof., Universidade Federal do Pará, UFPA, Castanhal, PA, Brasil.E-mail: geringbr@yahoo.com.br

${ }^{4}$ Discentes de Doutorado, Universidade Estadual Paulista, UNESP, Jaboticabal, SP, Brasil.E-mail:lellyfaria@hotmail.com; paloma_ess@yahoo.com.br; cleber.ido@hotmail.com; helenrobeta.medvet@hotmail.com

5 Discente de Mestrando, Universidade Estadual Paulista, UNESP, Jaboticabal, SP, Brasil. E-mail: diegoyamada2889@gmail.com

6 Prof., Universidade Estadual Paulista, UNESP, Jaboticabal, SP, Brasil. E-mail: newton@fcav.unesp.br

Author for correspondence
} 


\title{
Resumo
}

\begin{abstract}
Objetivou-se com este trabalho avaliar os efeitos da associação de óxido nitroso $\left(\mathrm{N}_{2} \mathrm{O}\right)$ ao oxigênio, na proporção de $50 \%$ cada, sobre os parâmetros cardiovasculares em suínos anestesiados com propofol e mantidos em ventilação com pressão positiva intermitente. Para isso, foram utilizados 16 suínos da raça Large White com pesos entre 15 e $20 \mathrm{~kg}$, distribuídos em dois grupos de oito animais cada, assim nomeados: GPN (GrupoPropofol/Óxidonitroso) e GPA (GrupoPropofol/Arcomprimido). Os animais receberam azaperona $\left(2 \mathrm{mgkg}^{-1}, \mathrm{IM}\right)$ e após 20 minutos, administrou-se propofol por via intravenosa, em doses suficientes para permitir a intubação traqueal. Após intubação, iniciou-se a infusão contínua de propofol na dose de $0,4 \mathrm{mgkg}^{-1}$ minuto ${ }^{-1}$. A partir deste momento, os animais do GPN receberam $\mathrm{N}_{2} \mathrm{O}$ diluído em $50 \%$ de oxigênio e os do GPA, ar comprimido diluído em $50 \%$ de oxigênio. Ato contínuo, administrou-se, por infusão intravenosa contínua, rocurônio a $0,6 \mathrm{mgkg}^{-1} \mathrm{~h}^{-1}$. A ventilação controlada a pressão (VCP) foi iniciada e ajustada a $15 \mathrm{cmH}_{2} \mathrm{O}$ e a freqüência respiratória foi regulada para alcançar valores de capnometria entre $35-45 \mathrm{mmHg}$. A medição dos parâmetros (freqüência cardíaca, pressão arterial média, índice cardíaco, índice da resistência periférica total, índice sistólico) iniciou-se após 15 minutos da administração de rocurônio, repetindo-se a cada 15 minutos, durante um intervalo de 60 minutos. Os dados foram submetidos à análise estatística pela ANOVA seguida pelo teste de Bonferroni. Os resultados mostraram que a associação do óxido nitroso ao oxigênio na proporção de $50 \%$ cada em suíno anestesiado com propofol e mantido em ventilação controlada à pressão não provoca alterações cardiovasculares clinicamente relevantes.
\end{abstract}

Palavras-chave: Anestesia balanceada. Índice cardíaco. Monitoração hemodinâmica.

Nitrous oxide $\left(\mathrm{N}_{2} \mathrm{O}\right)$ is a non-explosive inorganic anesthetic gas widely used in clinical practice for its analgesic and sedative capacity. In the context of balanced anesthesia, $\mathrm{N}_{2} \mathrm{O}$ has been successfully used in various protocols; however, the use of this gas in combination with other agents is associated with a reduction in the concentration or dose of the agent employed due to the analgesic effects of $\mathrm{N}_{2} \mathrm{O}$ (FALEIROS et al., 2014). Among the general anesthetics currently used, propofol is as an excellent intravenous drug that provides rapid recovery with little cumulative effect (NUNES et al., 2008). However, propofol has no significant analgesic action, and is therefore used in combination with other agents that provide analgesia, such as $\mathrm{N}_{2} \mathrm{O}$.

The use of isolated $\mathrm{N}_{2} \mathrm{O}$ is contra indicated due to the occurrence of cerebral hypoxia. As such, it is generally recommended that $\mathrm{N}_{2} \mathrm{O}$ should be used in combination with a minimum of $30 \%$ oxygen $\left(\mathrm{O}_{2}\right)$ (NISHIMORI et al., 2008). Because $\mathrm{N}_{2} \mathrm{O}$ is a relatively soluble inert gas, very high concentrations in the gas mixture can result in its rapid transfer to the blood, causing absorption atelectasis (LOPES; NUNES, 2010). Therefore, when $\mathrm{N}_{2} \mathrm{O}$ is employed, the use of pressure-controlled mechanical ventilation (PCV) may contribute to a reduction in areas of atelectasis and improved ventilation/perfusion ratio (FU et al., 2014).

Depending on the dose used, propofol can induce significant cardiovascular effects such as hypotension and bradycardia (FANTONI et al., 2002). Additionally, decreases in venous return to the right ventricle and in cardiac output are the most important hemodynamic changes that occur during mechanical ventilation (ROMALDINI, 2006). In contrast, $\mathrm{N}_{2} \mathrm{O}$ directly depresses myocardial function, but its property of sympathetic stimulation in turn suppresses the direct myocardial depression that it causes (CARROLL, 2012), raising a number of important questions, notably: (1) Do the advantages attributed to $\mathrm{N}_{2} \mathrm{O}$ outweigh its harmful effects on gas exchange? (2) Could the introduction of this anesthetic gas attenuate the hemodynamic benefits of intravenous agents such as propofol that may be used in association with $\mathrm{N}_{2} \mathrm{O}$ ?

In order to analyze the advantages or disadvantages of the introduction of $\mathrm{N}_{2} \mathrm{O}$ as an adjunct to intravenous anesthesia by propofol, 
the aim of this study was to determine the effects of $50 \% \mathrm{~N}_{2} \mathrm{O}$ on cardiovascular parameters in pigs anesthetized with propofol and maintained in pressure-controlled ventilation.

This study was approved by the Ethics Committee on Animal Use (CEUA) of FCAV/ UNESP under protocol No. 026519. Sixteen Large White pigs were used (male or female, about seven weeks of age and weighing between 15 and 20 $\mathrm{kg}$ ). The animals were considered healthy after: (i) physical examination (color of mucous membranes, cardiopulmonary auscultation, body temperature and abdominal palpation), (ii) diagnostic support examination (blood test and chest x-rays) and (iii) examination to confirm absence of lung disease. The animals were provided by a farm specialized in breeding pigs and were kept in community stalls and maintained on commercial feed and water ad lib, which was replaced every 12 hours.

After randomization, the pigs were divided into two groups of eight (four males and four females each), designated PGN (Propofol Group/Nitrous Oxide) and PGA (Propofol Group/Compressed Air). At the end of the assessment period, the animals were returned to the pig farming industry for growing and fattening.

Prior to the procedure, the animals were subjected to 12-hour food-fasting and 2-hour waterfasting periods. Following the fasting periods, each pig received azaperone (Stresnil®)-Janssen Pharmaceutica - São Paulo- SP) at a dose of $2 \mathrm{mg}$ $\mathrm{kg}^{-1}$, administered intramuscularly in the left thigh. After sedation was established (an average of 15 minutes), trichotomy and antisepsis of the external faces of the right and left auricular pavilions were carried out. Then, the right and left auricular veins were catheterized (Cateter BD Angiocath ${ }^{\circledR} 22$ GBecton, Dickinson Indústria Cirúrgica Ltda - Juiz de Fora, MG) for the administration of drugs.

Anesthesia was induced with intravenous propofol (13.18 $\pm 2.55 \mathrm{mg} \mathrm{kg} \mathrm{kg}^{-1}$ ) (Propovan ${ }^{\circledR}$ Propofol - Cristália-Itapira - SP) at the dose required for the loss of laryngotracheal reflex. Immediately after, the animals were placed in the left lateral decubitus on active thermal mattress (GAYMAR - mod. TP - 500 - Londres, Inglaterra) and the continuous infusion of propofol began at the rate of $0.4 \mathrm{mg} \mathrm{kg}^{-1} \mathrm{~min}^{-1}$, through an infusion pump (Bomba de seringa AS50, SAMTRONIC $\AA$, São Paulo - SP). Subsequently, we proceeded with orotracheal intubation with a Magill tube of diameter suitable for the size of each pig (6.0 to 6.5). The Magill tube was coupled to the inhalation anesthesia apparatus of an anesthetic circuit with a carbon dioxide scrubber equipped with volumetric/ pressuremetric ventilator (Takaoka Aparelho volumétrico/pressométrico - mod. FAT 500), and installed in line with the valve filter for the supply of the gaseous mixture. From this moment, the animals in the GPN group received $\mathrm{N}_{2} \mathrm{O}$ diluted in oxygen at 50\%, while the animals in the GPA group underwent the same method, but the anesthetic gas was replaced by compressed air diluted in oxygen at $50 \%$. The reading of the concentration of $\mathrm{O}_{2}$ and $\mathrm{N}_{2} \mathrm{O}$ was obtained five minutes after induction using a multiparameter monitor (DIXTAL - mod. DX 2010 LCD - Manaus - AM) whose gas analyzer sensor was attached to the proximal end of the orotracheal tube after intubation.

Subsequently, the cervical region was shaved and disinfected for skin incision and exposure of the jugular vein. The jugular vein was then isolated and catheterized with a Swan-Ganz catheter (Cateter Swan-Ganz Pediátrico, mod. 1325f, 4 vias Edwards Lifesciences LLC, Irvine, CA, EUA), whose end was positioned inside the lumen of the pulmonary artery; this was confirmed by observation of pressure waves, according to the technique described by Swan-Ganz and cited by Souza et al. (2004). The inner side of the left thigh was shaved for transcutaneous catheterization of the femoral artery where a pressure transducer was connected and attached to a multiparameter monitor to measure blood pressure. 
After 125 minutes of anesthetic induction (the time required for instrumentation of the animals), rocuronium was administered intravenously at a dose of $0.6 \mathrm{mg} \mathrm{kg}^{-1}$. Throughout the experimental period, continuous infusion of muscle relaxant was continuously administered through an infusion pump at a dose of $0.6 \mathrm{mg} \mathrm{kg}^{-1} \mathrm{~h}^{-1}$. We then began the controlled ventilation with intermittent positive pressure a peak inspiratory pressure of $15 \mathrm{~cm} \mathrm{H}_{2} \mathrm{O}$. The total flow of the inhaled gas was set between 30 and $50 \mathrm{~mL} \mathrm{~kg}^{-1} \mathrm{~min}^{-1}$, with sufficient inspiration/ expiration ratio, amplitude, and respiratory rate to allow for capnometry reading, which was achieved by measuring the partial pressure of $\mathrm{CO}_{2}$ at the end of exhalation (between 35 and $45 \mathrm{mmHg}$ ) using an oxicapnograph (DIXTAL - mod. CO2SMO 7100) whose sensor was positioned at the distal end of the orotracheal tube and connected to the anesthesia equipment. Once these parameters were set, they were not changed throughout the experimental protocol.

Measurement of the variables of interest began 140 minutes after induction of anesthesia (M0), and repeated every 15 minutes over a period of 60 minutes (M15, M30, M45 and M60). For measurement of the cardiac output ( $\mathrm{CO}$ ), necessary for calculation of the cardiac index [CO divided by body surface area (BSA) in $\mathrm{m}^{2}$ ], we used a microprocessor device for direct measurement of $\mathrm{CO}$ through the thermodilution technique (SOUZA et al., 2004). The Average Blood Pressure was measured by direct reading, in $\mathrm{mmHg}$, using a multi-parameter monitor whose transducer was connected to the catheter inserted in the left femoral artery and positioned at the heart level as "zero reference" for calibration. Measurement of the Heart Rate (HR) was obtained in beats/minute, by observing the R-R wave intervals, through computerized electrocardiograph (TEB-mod.ECGPC Software versão 1.10- São Paulo - SP), and adjusted for reading in lead DII.

The Stroke Index (SI) in $\mathrm{mL}$ beat ${ }^{-1} \mathrm{x} \mathrm{m}^{2}$, and the Total Peripheral Resistance Index (TPRI) in dyne $x$ sec $\mathrm{cm}^{5-1} \mathrm{x} \mathrm{m}^{2}$, were obtained using the formulas: $\mathrm{SI}=\mathrm{SV} / \mathrm{BSA}$, where $\mathrm{SV}=$ Systolic Volume $(\mathrm{CO} /$
$\mathrm{HR}), \mathrm{BSA}=$ Body Surface Area $\left(\mathrm{m}^{2}\right)$ and TPRI = $(\mathrm{MBP} / \mathrm{CO}) \times$ 79.9/BSA, where $79.9=$ Correction Factor $\left(\mathrm{mmHg} \times \operatorname{min~} \mathrm{L}^{-1}\right.$ dyne $\left.\mathrm{x} \sec \mathrm{cm}^{5-1}\right)$. The data were analyzed for statistical significance by the GraphPadPrism 5 computer program for Windows. In order to analyze the normal distribution of the samples, the Shapiro-Wilk test was used. To determine differences of averages between the groups, a two-way analysis of variance was performed (Two-way ANOVA), followed by the Bonferroni test. For comparison of the moments in each group over time, the one-way analysis of variance (One-way ANOVA) was used, for repeated measurements, followed by the Bonferroni test. Differences were considered significant at $\mathrm{p}<0.05$.

There was no significant difference between groups regarding the HR ( $p>0.05)$, but in the GPA group, there was significant variation over time ( $p<0.05$ ), as evidenced by decreased heart rate from M30 to M60 (Table 1). This event may have occurred due to the depressant effect of propofol on the heart (FANTONI et al., 2002). It is true that the HR also declined in the GPN group probably due to the sympathetic stimulation induced by the $\mathrm{N}_{2} \mathrm{O}$, which acts on the $\alpha 2$-adrenergic receptors (CARROLL, 2012). The highest average values of MBP in the GPN group, while not significantly different within the GPA group, may also be explained by the sympathetic stimulation typical of $\mathrm{N}_{2} \mathrm{O}$ (FANTONI et al., 2002).

Although $\mathrm{N}_{2} \mathrm{O}$ may discreetly raise the CI via its compensatory sympathetic activity (HOHNER; REIZ, 1994), while propofol tends to reduce it by decreasing peripheral vascular resistance (ROBINSON et al., 1997), in this study no differences were observed between groups and moments $(p>0.05)$. This finding corroborates the results of Inada et al. (1999), who demonstrated hemodynamic stability associated with the use of $\mathrm{N}_{2} \mathrm{O}$ and propofol. This finding is also consistent with a report by Nishimori et al. (2007), who also observed cardiovascular stability using propofol at a dose of $0.4 \mathrm{mg} \mathrm{kg}^{-1} \mathrm{~min}^{-1}$ in association with $30 \%$ $\mathrm{N}_{2} \mathrm{O}$. 
While the clinical significance is not clear, there was a trend of reduction in CI of 30 minutes from the experimental test in both groups. The increase in intrathoracic pressure generated by PCV will be transmitted to the right atrium, thus reducing the pressure gradient for venous return and leading to decreased venous blood flow from the systemic veins into this chamber (NAKAMURA; IANOTTI, 2014). This event results in a decrease in the enddiastolic volume in the left ventricle, and in the CO (ROMALDINI, 2006), which explains the slight reduction in the cardiac index in both groups. Moreover, the increase in the TPRI and in GPN, while not significant $(p>0.05)$, may also contribute to decreased venous return, because it provides increased after-load (MOHOVIC; KNOBEL, 2013), which leads to a slight decline in cardiac indexes. It is likely that sympathetic stimulation by $\mathrm{N}_{2} \mathrm{O}$ (CARROLL, 2012) may have promoted peripheral vasoconstriction, thus contributing to higher averages of IRPT in GPN, but without significant clinical consequences.

Table 1. Mean values and standard deviations $(\mathrm{x} \pm \mathrm{s})$ of the variables: heart rate $(\mathrm{HR})$, Mean Arterial Pressure (MAP), Cardiac Index (CI), the Total Peripheral Resistance Index (TPRI) and Systolic Volume (SV) obtained in pigs anesthetized with propofol associated with (GPN) or without (GPA) nitrous oxide, for a period of 60 minutes.

\begin{tabular}{|c|c|c|c|c|c|c|}
\hline Variables & & M0 & M15 & M30 & M45 & M60 \\
\hline \multirow{2}{*}{ HR (beats minute ${ }^{-1}$ ) } & GPA & $130 \pm 19^{a}$ & $118 \pm 19^{a}$ & $113 \pm 21^{b}$ & $109 \pm 21^{c}$ & $112 \pm 21^{\mathrm{d}}$ \\
\hline & GPN & $139 \pm 27$ & $127 \pm 22$ & $119 \pm 15$ & $116 \pm 10$ & $123 \pm 39$ \\
\hline \multirow{2}{*}{$\mathrm{ABP}(\mathrm{mmHg})$} & GPA & $84 \pm 15$ & $84 \pm 13$ & $85 \pm 15$ & $88 \pm 11$ & $90 \pm 13$ \\
\hline & GPN & $79 \pm 14$ & $84 \pm 20$ & $89 \pm 17$ & $92 \pm 21$ & $88 \pm 24$ \\
\hline \multirow{2}{*}{$\mathrm{CI}\left(\mathrm{L} \mathrm{min} \mathrm{min}^{-1} \mathrm{~m}^{2-1}\right)$} & GPA & $4.7 \pm 0.8$ & $4.9 \pm 1.0$ & $4.5 \pm 1.2$ & $4.4 \pm 1.0$ & $4.2 \pm 0.7$ \\
\hline & GPN & $4.6 \pm 1.4$ & $4.6 \pm 1.3$ & $4.4 \pm 1.6$ & $3.9 \pm 1.3$ & $4.0 \pm 1.4$ \\
\hline \multirow{2}{*}{ TPRI (dyne $\mathrm{x} \mathrm{sec} / \mathrm{cm}^{5} \mathrm{x} \mathrm{m}^{2}$ ) } & GPA & $3837 \pm 1198$ & $3806 \pm 1385$ & $4310 \pm 1826$ & $4441 \pm 1659$ & $4558 \pm 1053$ \\
\hline & GPN & $4543 \pm 3539$ & $4863 \pm 4356$ & $5630 \pm 5416$ & $6470 \pm 6268$ & $5718 \pm 4351$ \\
\hline \multirow{2}{*}{$\mathrm{SI}\left(\mathrm{mL} /\right.$ beat $\left.\mathrm{x} \mathrm{m}^{2}\right)$} & GPA & $36.6 \pm 6.8$ & $42.9 \pm 15.5$ & $40.7 \pm 12.6$ & $41.3 \pm 11.5$ & $37.6 \pm 7.2$ \\
\hline & GPN & $32.9 \pm 7.6$ & $36.2 \pm 9.3$ & $36.5 \pm 10.6$ & $33.7 \pm 10.6$ & $32.7 \pm 9.7$ \\
\hline
\end{tabular}

Means followed by different lower case letters, in the lines, differ significantly (one-way ANOVA for repeated measurements, followed by Bonferroni test $(\mathrm{p}<0.05))$.

We conclude that in pigs kept on ventilation with intermittent positive pressure, the addition of $\mathrm{N}_{2} \mathrm{O}$ at $50 \%$ as an adjunct to intravenous anesthesia with propofol does not cause clinically significant cardiovascular abnormalities.

\section{Acknowledgements}

The authors thank the Fundação de Amparo à Pesquisa do Estado de São Paulo (FAPESP), for granting of funds that made the execution of this work possible.

\section{References}

CARROLL, L. G. Anestésicos inalatórios. In: Anestesia e analgesia de pequenos animais. Barueri: Manole, 2012. cap. 7, p. 109-124.

FALEIROS, R. R.; ALVES, G. E. S.; SIQUEIRA, V. J.; MARQUES JÚNIOR, A. P. Viabilidade, segurança e praticidade da anestesia inalatória por halotano e óxido nitroso com intubação pré-indução em equinos. Veterinária Notícias, Uberlândia, v. 3, n. 1, p. 7-12, 2014.

FANTONI, D. T.; CORTOPASSI, S. R. G.; BERNARDI, M. M. Anestésicosinalatórios. In: SPINOSA, H. S.; GÓRNIAK, S. L.; BERNARDI, M. M. Farmacologia aplicada à medicina veterinária. 3. ed. Rio de Janeiro: Guanabara Koogan, 2002. cap. 10, p. 105-116. 
FU, C.; SILVEIRA, L. T. Y.; BERNARDES, S. R. N. Indicações da ventilação mecânica. In: CARR, A.M.G; BERALDO, M. Princípios e práticas de ventilação mecânica. 2. ed. Barueri: Manole, 2014. cap. 2, p. 6-15.

HOHNER, P.; REIZ, S. Nitrous oxide on the cardiovascular system. Acta Anaesthesiologica Scandinavica, Nova Zelândia, v. 38, n. 1, p. 763-66, 1994.

INADA, T.; SHINGU, K.; NAKAO, S.; NAGATA, A. Effects of nitrous oxide on haemodynamic and eletroencephalografic responses induced by tetanic electrical stimulation during propofol anaesthesia. Anaesthesia, Londres, v. 54, n. 5, p. 423- 25, 1999.

LOPES, P. C. F.; NUNES, N. Atelectasia pulmonar em cães durante anestesia geral. Ciência Rural, Santa Maria, v. 60 , n. 1, p. 266-253, 2010.

MOHOVIC, T.; KNOBEL, E. Variáveis hemodinâmicas calculadas: resistência e trabalho. In: AULER JÚNIOR, J. O.C.; AMARAL, R. V. G. Monitorização hemodinâmica no paciente grave. São Paulo: Atheneu, 2013. cap. 14, p. 165-176.

NAKAMURA, M. A. M.; IANOTTI, R. M. Mechanical ventilation in the postoperative períod of heart disease. In: CARR, A. M. G.; BERALDO, M. Mechanical ventilation principles and practices. $2^{\text {th }}$ ed. São Paulo: Manole, 2014. p. 182-95.

NISHIMORI, C. T.; NUNES, N.; SOUZA, A. P.; SANTOS, P. S. P.; PAULA, D. P.; REZENDE, M. L.; LEITE, A. V. Eletrocardiografia em cães anestesiados com diferentes concentrações de desfluorano associado ou não ao óxido nitroso. ARS Veterinária, São Paulo, v. 21, n. 2, p. 238-242, 2008.
NISHIMORI, C. T. D.; NUNES, N.; PAULA, D. P.; CARARETO, R.; LOPES, P. C. F.; CONCEIÇÃO, E. D. V.; SANTOS, P. S. P.; BARBOSA, V. F. Bispectral índex in dogs anesthetized with increasing and decreasing propofol infusion associated or not with nitrous oxide. ARS Veterinária, São Paulo, v. 23, n. 1, p. 8-18, 2007.

NUNES, N.; LOPES, P. C. F.; SANTOS, P. S. P. D.; PAULA, D. P. D.; NISHIMORI, C. T. D.; CARARETO, R.; CAMACHO, A. A. Hemodinâmica de diferentes frações inspiradas de oxigênio em cães submetidos à infusão contínua de propofol sob ventilação espontânea. Ciência Rural, Santa Maria, v. 38, n. 3, p. 729-735, 2008.

ROBINSON, B. J.; EBERT, T. J.; O`BRIEN, T. J.; COLINCO, M. D.; MUZI, M. Mechanisms whereby propofol mediates peripheral vasodilation in humans. Sympathoinhibition or direct vascular relaxation? Anesthesiology, Chicago, v. 86, n.3, p. 64-72, 1997.

ROMALDINI, H. Repercussões cardiovasculares da ventilação mecânica. In: AULER JÚNIOR, C. J. O.; AMARAL, R. V. G. Assistência ventilatória mecânica. São Paulo: Atheneu, 2006. p. 115-120.

SOUZA, A. P. D.; NISHIMORI, C. T.; SANTOS, P. S. P. D.; PAULA, D. P. D.; NUNES, N.; REZENDE, M. L. D.; HENAO-GUERRERO, P. N. Avaliação da buprenorfina pelas vias intravenosa ou intramuscular em cães anestesiados pelo desfluorano. Ciência Rural, Santa Maria, v. 34, n. 3, p. 809-814, 2004. 